\title{
DISASTER MANAGEMENT: AN INTEGRAL PART OF SCIENCE \& TECHNOLOGY SYSTEM AND LAND ADMINISTRATION-MANAGEMENT SYSTEM
}

\author{
T. Ghawana ${ }^{\mathrm{a}}$, S. Zlatanova ${ }^{\mathrm{b}}$ \\ ${ }^{a}$ Indo-French Centre for the Promotion of Advanced Research, Delhi, India, Email: tarungh@ gmail.com \\ b Department of Urbanism, Delft University of Technology, Delft, The Netherlands, Email: s.zlatanova@tudelft.nl
}

\section{Commission VIII, WG VIII/1}

KEY WORDS: Disaster Management, Science \&Technology System, Land Administration-Management System, Institutional
Linkages

\section{ABSTRACT:}

Disaster management is a multidisciplinary field, which requires a general coordination approach as well as specialist approaches. Science and Technology system of a country allows to create policies and execution of technical inputs required which provide services for the specific types of disasters management. Land administration and management agencies, as the administrative and management bodies, focus more on the coordination of designated tasks to various agencies responsible for their dedicated roles. They get help from Scientific and technical inputs \& policies which require to be implemented in a professional manner. The paper provides an example of such integration from India where these two systems complement each other with their dedicated services. Delhi, the Capital of India, has such a disaster management system which has lot of technical departments of government which are mandated to provide their services as Emergency Service Functionaries. Thus, it is shown that disaster management is a job which is an integral part of Science \& Technology system of a country while being implemented primarily with the help of land administration and management agencies. It is required that new policies or mandates for the Science and technology organizations of government should give a primary space to disaster management

\section{BACKGROUND}

Disaster management is a multidisciplinary field which comes under the purview of various systems for coordination and execution of activities. Different types of disasters need thematic specialist approaches due to their very nature of specific events. However, there are some common characteristics of institutional arrangements which are required under a disaster management framework Asia faces highest number of natural disasters. Floods and landslides are common disasters in India. They cause damages in terms of human lives as well as infrastructure loss. By creating crisis / emergency situation mechanisms as integral part of policy and planning, India can avert such damages or reduce the impact of disasters. R \& D in science and technology should focus more on reduction and mitigation measures. Translating scientific information in useful information for executing agencies is required for the success of an integrated disaster management system. There is a need to convert the scientific conclusions into simpler terms which can be understood by the non-scientific and non-technical people from land administration and management system. (Neuvel et.al, 2006; Zlatanova et.al, 2006; Borkulo et. al, 2005; Cutter et.al, 2003; Noran, O., 2014, Guzman, 2003).

Advanced modeling systems are now in place many countries including India which can provide the planners predictive simulations under different levels of flood so as to create preventive measures. Advancement in GIS and Remote Sensing technologies has enabled to create spatial visualization in easy manner (HecRAS, ArcSWAT, Mike 11). A water resource management policy can make provisions for using technical advancements in this field as preventive measures against floods (UNISDR, 2009; JICA). Flood Warning System from Central Water System is an existing example of this. Similarly Ministry of Earth Sciences, Government of India R \& D activities in Ocean based research can try to minimize the impact of Cyclones and Tsunami like disaster (MOES; NOAA Center for Tusnami Research; Nature Geoscience, 2013). In urban areas like Delhi, due to high congestion of traffic, the problem of response time by Fire department is quite high. An
Intelligent Transport System can take care of it using Automatic routing, traffic lights etc. (Kashif, 2013). The dedicated modeling systems are available to help the planners \& decision makers. Transcad and Cube are some of the popular software with modelling options for various challenges in transport planning. Again inputs from GIS and Remote Sensing technologies are embedded in such systems. Technical departments of Utility Service providers can implement such provisions by nodal ministries and R \& D based outputs to real test.

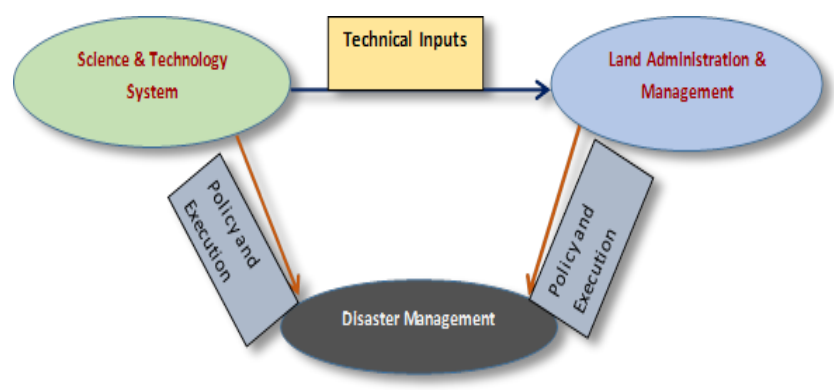

Figure 1: Conceptual Diagram of Disaster Management linkages with S \& T System and Land Admin. \& Management

India as a large country has a big administrative system which is largely responsible on execution level for the disaster management. With the growing natural calamities related to climate change and the increased rate of urbanization, it is required that the entities coming under the administrative system must have the coordination level high enough to implement the scientific inputs from the scientific and technical departments. Without the implementation on the ground level, the scientific information generation and its analytical value is of hardly any use except for policy making. Policies must define mechanisms also for implementation while considering the situations during a disaster event. The scientific analysis has to be incorporated in the execution plans for disaster management but must consider 
the role of various stakeholders in the form of self-help groups from community, private firms, government departments and international organizations involved with such events. India has a large network of NGOs working in Urban and Rural areas. It also has the significant presence of international institutional mechanism. To take leverage of such mechanisms presence and to exploit it to its full potential, integrated disaster management is a must requirement.

In this study, it is aimed to highlight the disaster management, as shown in Figure 1, as an integral part of science \& technology system of a country as well as its land administration system. This will create an increased understanding of the policy and execution level coordination activities with generic and specific requirements. For this purpose, the potential linkages of Disaster Management are shown with various entities coming under Indian Science \& Technology Management System. Linkages between Land Administration \& Management System of Delhi, the capital of India, with Delhi Disaster Management are also explored. Thus the linkages are explored at two different geographical scopes of national and provincial level.

The paper briefly describes the Indian disaster management framework involving a brief background of evolution of disaster management authorities at various levels and the significant role of ministry of home affairs. It goes on describing the relation of Indian science and technology system with disaster management in general which involves various ministries and the nodal departments responsible for different types of disasters. It proceeds with giving brief details about Delhi, the capital of India, disaster management system. Further, it goes on detailing the various entities of land administration system of Delhi including their main functions and what role is played by various entities of this system in disaster management.

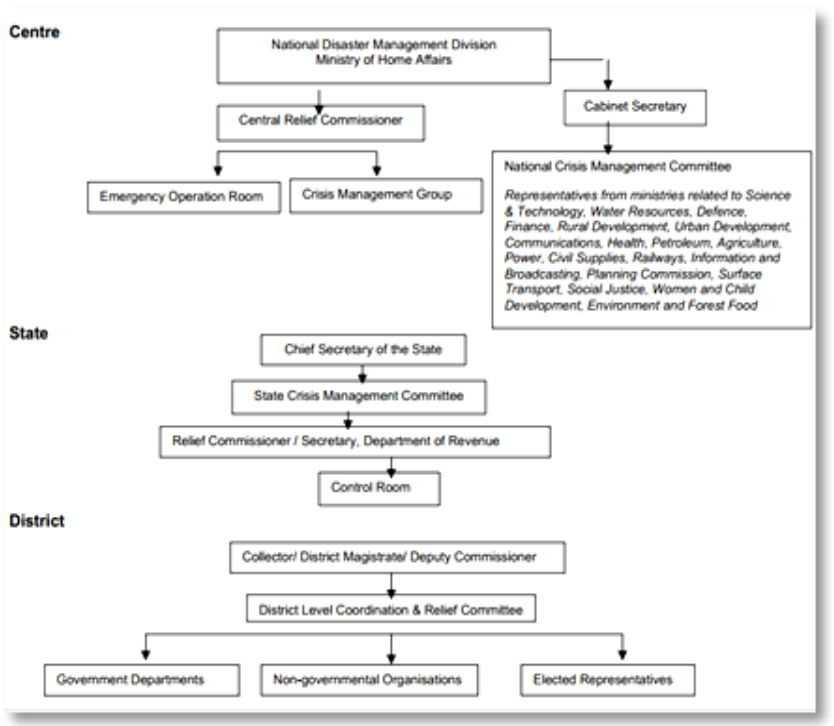

Figure 2: Institutional Structure for Disaster Management in India; (Source: Patwardhan et al, 2007)

\section{INDIAN DISASTER MANAGEMENT FRAMEWORK}

Indian actions on Disaster Management took an institutional shape, as shown in Figure 2, first time in the form of Natural Disaster Management Division under Ministry of Agriculture in year 1992. Later, in 1996, Agriculture ministry setup National Centre for Disaster Management. In 2002, report of the High Powered Committee on Disaster Management came out and in 2003,
Disaster Management mandate was shifted under Ministry of Home Affairs. In 2005, Disaster Management Act came which paved the way for the establishment of National Disaster Management Authority, State and District Management Authorities as shown in Figure 2 (Patwardhan et. al, 2007).

Ministry of Home Affairs is a central government entity responsible for disaster management activities in whole India. It has a National Disaster Management Division. The Division is responsible for response, relief and preparedness for natural calamities and man-made disasters (except drought and epidemics). The Division is also responsible for legislation, policy, capacity building, prevention, mitigation and long term rehabilitation (MHA-NDMI).

In this context, it is imperative to mention a Pan India initiative of the ministry. The IDRN (India Disaster Resource Network www.idrn.gov.in) is a nation-wide electronic inventory of essential and specialist resources for disaster response, covering specialist equipment, specialist manpower resources and critical supplies. IDRN has been initiated by Ministry of Home Affairs (MHA) in collaboration with United Nations Development Program (UNDP) to systematically build the disaster resource inventory as an organized information system for collection and transmission of information about specific equipment, human expertise and critical supplies database from District level to State level to provide availability of resources for disaster response, so that disaster managers can mobilize the required resources within least response time (MHA-IDRN).

\section{INDIAN SCIENCE AND TECHNOLOGY SYSTEM- RELATION WITH DISASTER MANAGEMENT}

Department of Science and Technology, Ministry of Science and Technology, Government of India, is established with the objective of promoting new areas of Science \& Technology and to play the role of a nodal department for organizing, coordinating and promoting S\&T activities in the country. Figure 3 presents Indian S \& T system in graphic mode while focusing on central government $S \& T$ structure \& its functioning hierarchy. Based on this, the present study tries to establish disaster management as an integral part of mandate / objectives of the planning commission \& mentioned $S \& T$ ministries. Corresponding organizations down in the hierarchy to these ministries and the planning commission are not explored further due to the limited scope of this study as well as considering the same mandate as of ministries \& planning commission.

In addition to the ministries mentioned in the above $\mathrm{S} \& \mathrm{~T}$ system, it is important to describe the role of Ministry of Water Resources, River Development \& Ganga Rejuvenation and Ministry of New \& Renewable Energy as a part of Indian S \& T system due to its scientific \& technological activities as well as their role in Indian Disaster Management activities. The role of Department of Atomic Energy and Department of Space, which is directly under Indian Prime Minister, is also described.

Gautam P. K., 2013, mentioned nodal ministries for disaster management which is referenced from National Disaster Management Authority website, accessed on June 23, 2011. It includes many ministries mentioned in our $\mathrm{S} \& \mathrm{~T}$ System as nodal point for particular disasters grouped under broad classification. 


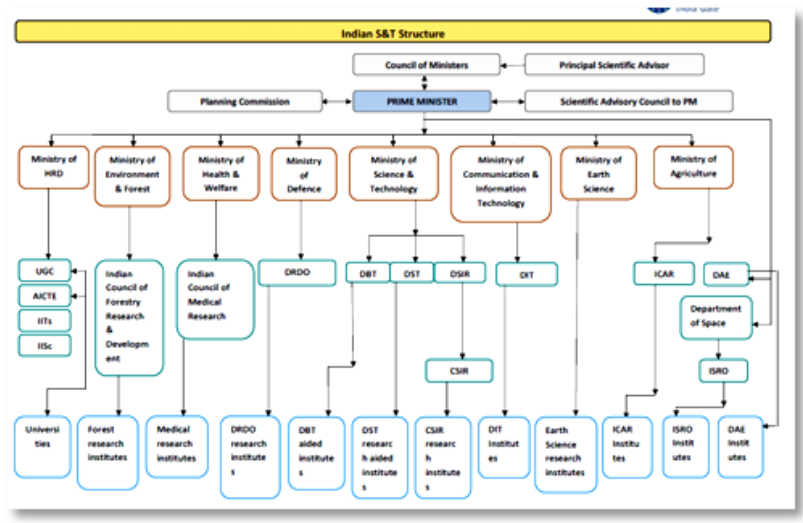

Figure 3: Indian S \& T Structure; (Source: IndiaGate, European Commission, image)

Gautam P. K., 2013, mentioned nodal ministries for disaster management which is referenced from National Disaster Management Authority website, accessed on June 23, 2011. It includes many ministries mentioned in our S \& T System as nodal point for particular disasters grouped under broad classification.

\begin{tabular}{|l|l|}
\hline Disasters & Nodal Ministry \\
\hline $\begin{array}{l}\text { Earthquake and } \\
\text { Tsunami }\end{array}$ & MHA/Ministry of Earth Sciences/IMD \\
\hline Floods & $\begin{array}{l}\text { MHA/Ministry of Water } \\
\text { Resources/CWC }\end{array}$ \\
\hline Cyclones & MHA/Ministry of Earth Sciences/IMD \\
\hline Drought & Ministry of Agriculture \\
\hline Biological Disasters & Ministry of Health and Family Welfare \\
\hline Chemical Disasters & Ministry of Environment \& Forests \\
\hline Nuclear Disasters & Ministry of Atomic Energy \\
\hline Air Accidents & Ministry of Civil Aviation \\
\hline Railway Accidents & Ministry of Railways \\
\hline
\end{tabular}

Table 1: Nodal Ministries for Disaster Management

Based on the information available with various ministries, Table 2 provides specific disaster type focus and department/division of the ministries

\begin{tabular}{|l|l|l|}
\hline \multicolumn{1}{|c|}{ Ministry } & $\begin{array}{l}\text { Department } \\
\text { /Division }\end{array}$ & \multicolumn{1}{|c|}{ Focus Disaster Type } \\
\hline Agriculture & $\begin{array}{l}\text { Department of } \\
\text { Agriculture } \\
\text { and } \\
\text { Cooperation } \\
\text { (DAC); } \\
\begin{array}{l}\text { Drought } \\
\text { Management } \\
\text { Division }\end{array}\end{array}$ & $\begin{array}{l}\text { Drought, Hail, Storm, pest } \\
\text { attack, frost/cold wave. } \\
\text { (DAC, 2015) }\end{array}$ \\
\hline Earth Sciences & IMD, INCOIS & $\begin{array}{l}\text { Tsunami, Earthquake, } \\
\text { Severe Weather Conditions } \\
\text { eg. Storm Surges, Flood } \\
\text { (MOES-IMD, 2015; DST- } \\
\text { Seismology, 2015; MOES- } \\
\text { INCOIS, 2015; MOES- } \\
\text { EWSTSS, 2015; MOES- } \\
\text { EHA, 2015) }\end{array}$ \\
\hline $\begin{array}{l}\text { Communicati } \\
\text { on \& }\end{array}$ & CERT-In & $\begin{array}{l}\text { Cyber Threats, Incidents } \\
\text { and Emergencies }\end{array}$ \\
\hline
\end{tabular}

\begin{tabular}{|c|c|c|}
\hline $\begin{array}{l}\text { Information } \\
\text { Technology }\end{array}$ & & $\begin{array}{l}\text { (MCIT-CERT-In, 2015; } \\
\text { National Cyber Security } \\
\text { Policy, 2013). }\end{array}$ \\
\hline $\begin{array}{l}\text { Science \& } \\
\text { Technology }\end{array}$ & $\begin{array}{l}\text { NRDMS; } \\
\text { Seismology } \\
\text { Division }\end{array}$ & $\begin{array}{l}\text { Earthquake, Landslides } \\
\text { (DST-Seismology, 2015; } \\
\text { DST Road Map-Landslide) }\end{array}$ \\
\hline Defence* & Coast Guard & $\begin{array}{l}\text { Oil Spill } \\
\text { (National Oil Spill Disaster } \\
\text { Contingency Plan, 2013) }\end{array}$ \\
\hline $\begin{array}{l}\text { Health \& } \\
\text { Welfare } \\
\end{array}$ & NACO & $\begin{array}{l}\text { HIV AIDS } \\
\text { (NACO, 2015) }\end{array}$ \\
\hline $\begin{array}{l}\text { Environment } \\
\& \text { Forest } * *\end{array}$ & $\begin{array}{l}\text { Hazardous } \\
\text { Substances } \\
\text { Management } \\
\text { Division }\end{array}$ & $\begin{array}{l}\text { Chemical Disaster } \\
\text { (MEFCC-HSMD, 2015) }\end{array}$ \\
\hline $\begin{array}{l}\text { Ministry of } \\
\text { Water Res., } \\
\text { River } \\
\text { Development } \\
\text { and Ganga } \\
\text { Rejuvenation }\end{array}$ & $\begin{array}{l}\text { Central Water } \\
\text { Commission }\end{array}$ & $\begin{array}{l}\text { Flood } \\
\text { (MOWRRDGR, 2015) }\end{array}$ \\
\hline $\begin{array}{l}\text { Department of } \\
\text { Atomic } \\
\text { Energy }\end{array}$ & -- & $\begin{array}{l}\text { Nuclear Disaster } \\
\text { (DAE, 2015) }\end{array}$ \\
\hline Dept.of Space & $\begin{array}{l}\text { Indian Space } \\
\text { Research } \\
\text { Organization }\end{array}$ & $\begin{array}{l}\text { Landslides, Cyclones, } \\
\text { Earthquakes, Coastal } \\
\text { Vulnerability } \\
\text { (DOS, 2015) }\end{array}$ \\
\hline $\begin{array}{l}\text { Planning } \\
\text { Commission }\end{array}$ & $\begin{array}{l}\text { Dedicated } \\
\text { Working } \\
\text { Groups, } \\
\text { Guidelines }\end{array}$ & $\begin{array}{l}\text { Flood, General } \\
\text { (Planning Commission; } \\
\text { Planning Commission, } \\
\text { 2011; Working Group on } \\
\text { Disaster Management, } \\
\text { 2006) }\end{array}$ \\
\hline
\end{tabular}

* Indian Armed forces, under Ministry of Defence, help towards disaster response in general

** Environment, Forest and Climate Change

Table 2: S \& T ministries of India and focus on specific disaster type

\section{DISASTER MANAGEMENT SYSTEM OF DELHI}

According to Indian Disaster Management Act 2005, Delhi Disaster Management Authority and other relevant committees $\&$ functionaries had been established. The figures $4 \mathrm{a}$ show the organizational structures.

Principle Secretaries of Home, PWD, Revenue and Urban Development are Committee members. District Disaster Management Authority is headed by District Magistrate as Chairman. Senior officers of Police, Municipal Corporation, PWD and Health are Authority members.

In the district level authority as well as ESF (Figure $4 \mathrm{~b}$ and Table 3 ), the involvement of various administrative and thematic agencies is clearly visible. This includes security agencies, land management agencies as well as utility service providers. State Executive Committee of DDMA is headed by Chief Secretary as CEO. 


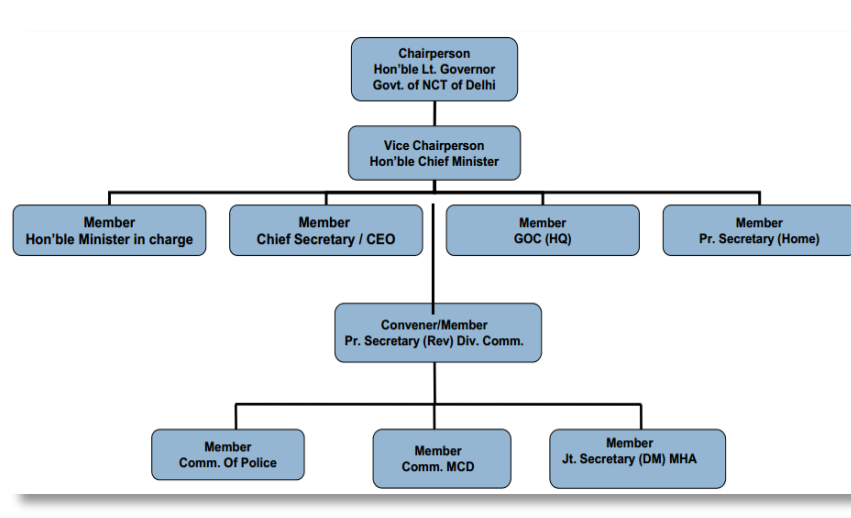

Figure 4a: Delhi Disaster Management Authority (Source: DDMA-GNCTD)

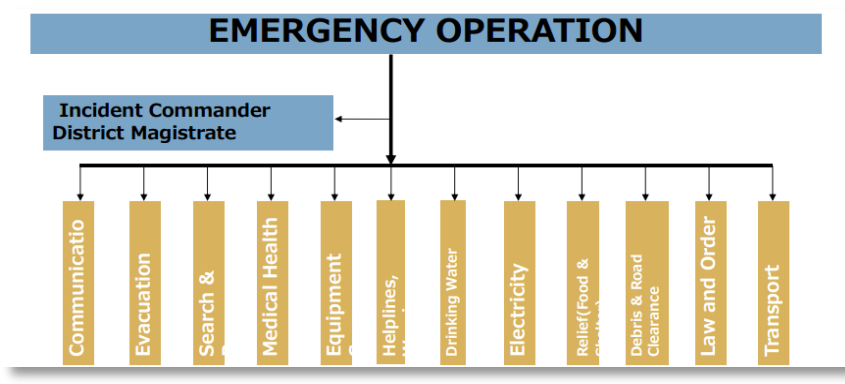

Figure 4b: Emergency Support Function (Source: DDMAGNCTD)

4.1 Delhi Land Administration and Management SystemRelation with Disaster Management

In this section, various entities of Delhi are included which are involved in land administration or management primarily and contribute towards the disaster management activities in Delhi Emergency Support Functionaries Framework, which are given as follows:

- Revenue Department, GNCTD - Delhi is divided in Eleven Revenue District. The District Administration carries out variety of functions including magisterial matters, revenue courts, issue of various statutory documents, registration of property, conduct of elections, relief \& rehabilitations, land acquisition and various other areas. (Revenue Department, Delhi)

- Urban Development Department, GNCTD - Plan for various infrastructure facilities and essential services being implemented by various agencies for works such as Water Supply, Sewage Disposal \& Sanitation, Urban Poverty Alleviation and various municipal services; formulates policy, provides funds, monitors and coordinates the activities, of the Urban Local Bodies, (Urban Development Department, Delhi)

- Central Public Works Department Delhi (CPWD)- A comprehensive construction management department, which provides services from project concept to completion, and maintenance management (CPWD, MoUD)

- Public Works Department, GNCTD (PWD)- Engaged in planning, designing, construction and maintenance of Government assets in the field of built environment and infrastructure development (Public Works Department, Delhi).

- Municipal Corporations of Delhi (MCD) - Responsibility of maintaining, upgrading and developing civic amenities efficiently (MCD, Delhi).

\begin{tabular}{|c|c|c|c|}
\hline 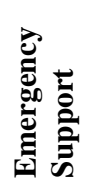 & $\begin{array}{l}z \\
0 \\
0 \\
\vdots \\
\vdots \\
\vdots \\
2\end{array}$ & 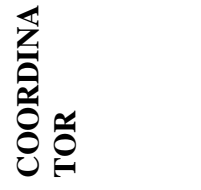 & 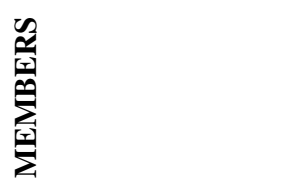 \\
\hline ESF1 & $\begin{array}{l}\text { Communic } \\
\text { ation }\end{array}$ & MTNL & $\begin{array}{l}\text { NIC, Police, Revenue } \\
\text { Wireless, } \\
\text { Telecom }\end{array}$ \\
\hline ESF2 & Evacuation & $\begin{array}{l}\text { Police } \\
\text { Department }\end{array}$ & $\begin{array}{l}\text { Army, Health Dept., } \\
\text { Civil Defence, Delhi } \\
\text { Fire Service, NCC }\end{array}$ \\
\hline ESF3 & $\begin{array}{ll}\text { Search \& } \\
\text { Rescue }\end{array}$ & $\begin{array}{l}\text { Secretary } \\
\text { Home }\end{array}$ & $\begin{array}{l}\text { Fire Deptt., Police, } \\
\text { Civil Defence, Army }\end{array}$ \\
\hline ESF4 & $\begin{array}{l}\text { Medical } \\
\text { Health/Tra } \\
\text { uma }\end{array}$ & $\begin{array}{l}\text { Secretary } \\
\text { Health }\end{array}$ & $\begin{array}{lr}\text { Major } & \text { Hospitals, } \\
\text { CATS, St. } & \text { John } \\
\text { Ambulance, } & \text { Civil } \\
\text { Defence } & \end{array}$ \\
\hline ESF5 & $\begin{array}{l}\text { Equipment } \\
\text { Support }\end{array}$ & $\begin{array}{l}\text { Secretary } \\
\text { Urban } \\
\text { Development }\end{array}$ & $\begin{array}{l}\text { MCD, PWD, NDMC, } \\
\text { DCB, DDA, Jal } \\
\text { Board }\end{array}$ \\
\hline ESF6 & $\begin{array}{l}\text { Helplines, } \\
\text { Warning } \\
\text { Disseminati } \\
\text { on \& } \\
\text { Coordinatio } \\
\text { n Media } \\
\text { Coverage }\end{array}$ & $\begin{array}{l}\text { Principle } \\
\text { Secretary } \\
\text { (Revenue/Dis } \\
\text { aster } \\
\text { Management) }\end{array}$ & $\begin{array}{l}\text { All Emergency } \\
\text { Support } \\
\text { Functionaries (ESFs), } \\
\text { Media Agencies }\end{array}$ \\
\hline ESF7 & $\begin{array}{l}\text { Drinking } \\
\text { Water } \\
\end{array}$ & $\begin{array}{ll}\text { CEO, Jal } \\
\text { Board }\end{array}$ & DJB \\
\hline ESF8 & Electricity & $\begin{array}{l}\text { Secretary } \\
\text { Power }\end{array}$ & $\begin{array}{ll}\text { Transco, } & \text { Power } \\
\text { Companies } & \\
\end{array}$ \\
\hline ESF9 & $\begin{array}{ll}\text { Relief } & \\
\text { (Food \& } \\
\text { Shelter) }\end{array}$ & $\begin{array}{l}\text { Principle } \\
\text { Secretary } \\
\text { (Revenue/ } \\
\text { Disaster } \\
\text { Management) }\end{array}$ & $\begin{array}{l}\text { Civil Supplies } \\
\text { Corporation, Civil } \\
\text { Defence, Volunteer } \\
\text { Organization, }\end{array}$ \\
\hline $\begin{array}{l}\text { ESF1 } \\
0\end{array}$ & $\begin{array}{l}\text { Debris \& } \\
\text { Road } \\
\text { Clearance }\end{array}$ & $\begin{array}{l}\text { Commissioner } \\
\text {, MCD }\end{array}$ & $\begin{array}{l}\text { PWD, NDMC, Cantt. } \\
\text { Board, DDA, MES, } \\
\text { CPWD }\end{array}$ \\
\hline $\begin{array}{l}\text { ESF1 } \\
1\end{array}$ & $\begin{array}{ll}\text { Law and } \\
\text { Order }\end{array}$ & $\begin{array}{l}\text { Commissioner } \\
\text {, Police }\end{array}$ & $\begin{array}{l}\text { Civil Defence, Home } \\
\text { Guards }\end{array}$ \\
\hline $\begin{array}{l}\text { ESF1 } \\
2\end{array}$ & Transport & $\begin{array}{l}\text { Secretary } \\
\text { Transport }\end{array}$ & DTC, DMRC \\
\hline
\end{tabular}

Table 3: ESF Delhi; Source: DDMA-GNCTD

- New Delhi Municipal Council (NDMC)-New Delhi Municipal Council consists of only 3 per cent of the area and 3 per cent of the population of National Capital Territory of Delhi. (New Delhi Municipal Council, 2015).

- Delhi Cantonment Board (DCB)- Board functions as a local municipal body for Delhi Cantonment Area (DCB, MOD).

- Delhi Development Authority (DDA)- To formulate a Master Plan for covering the present and future growth of Delhi; To acquire, hold, manage and dispose of land and other property; To carry out building, engineering, mining and other operations (DDA, 2015).

- Delhi Jal Board (DJB)- production and distribution of drinking water; treatment and disposal of waste water through an efficient network of about $7000 \mathrm{Km}$ of Sewage lines across Delhi (Delhi Jal Board, Delhi).

- Delhi Transco- Generation and transmission of Electricity in Delhi (Delhi Transco Limited).

- Delhi Metro Rail Corporation (DMRC)- Implementation and subsequent operation of Delhi MRTS (DMRC, Delhi) 
- Delhi Transport Corporation (DTC) - To provide or secure or promote an efficient, economical, reliable and properly coordinated system the road transport in Union Territory of Delhi and any extended area (DTC, 2015).

These entities look at planning to execution stages of land related developments and maintenance. In addition, the utility services providing institutions are also contributing towards the emergency support. The utility services consume land space in $2 \mathrm{D}$ as well as $3 \mathrm{D}$.

\section{DISCUSSION}

Indian disaster management system has taken a holistic approach by including various entities of $\mathrm{S} \& \mathrm{~T}$ system and land administration \& management system as shown in Figure 1. Central ministries of $S \& T$ themes carry a responsibility of national scale as nodal ministries for thematic disaster types. The various ministries or their line departments are responsible for execution of the policies but it is a fact that they have to work in tandem with the (land) administration agencies. The policies and execution system of scientific departments and land administration system aim to do the disaster management although with different orientations.

Ministry of Home Affairs (MHA) is the nodal agency with overall coordination responsibility for disaster management at national scale. Delhi, being the national capital territory has dual administration mechanisms by central as well as its own state government. Its disaster management system, clearly distributes the responsibility among the various agencies and most of them belong to Delhi land administration system in one way or the other. In the light of these facts, it can be inferentially drawn that our national $\mathrm{S} \& \mathrm{~T}$ policies should include disaster management as a proactive planning step with provisions and measures to be taken for Disaster Risk Reduction and Response phases. Currently Indian Science, Technology and Innovation policy 2013 has no such provision. It vaguely hints this way by stating that new structural mechanisms and models are needed to address the pressing challenges of energy and environment, food, water and sanitation, habitat, affordable health care etc. but there is no direct indication towards disaster management. It also mentions of serving as a source of strategic knowledge to cope with the challenges of climate variability and change (Indian STI Policy, 2013).

\section{REFERNCES}

ArcSWAT; Blackland Texas Research Centre, Soil and Water Assessment Tool; Website: swat.tamu.edu/software/arcswat/

Borkulo, E van, H.J. Scholten, S. Zlatanova and A van den Brink, 2005, Decision making in response and relief phases, In: van Oosterom, Zlatanova\&Fendel (Eds.), Geo-information for disaster management - late papers, pp. 47-54

CPWD, MoUD; Central Public Works Department, Ministry of Urban Development; Website: http://cpwd.gov.in/

Cube; Website: www.citilabs.com/software/cube/

Cutter, S.L., Richardson D. B. and Wilbanks T.J. (eds.) 2003, The Geographical Dimensions of terrorism, Taylor and Francis, New York, ISBN 0-415-94641-7

DAC, 2015; Department of Agriculture And Cooperation, Ministry of Agriculture, Cooperation \& Farmers Welfare Website: http://agricoop.nic.in/
DAE, 2015; Department of Atomic Energy; Website: http://dae.nic.in/?q=node/634

DCB, MOD; Delhi Cantonment Board, Ministry of Defence; Website: http://www.cbdelhi.in/

DDMA-GNCTD; Disaster Management in Delhi, Delhi Disaster Management Authority; Government of National Capital Territory of Delhi

Delhi Development Authority; Website: dda.org.in

Delhi Jal Board, Delhi; Website: http://www.delhi.gov.in/ wps/wcm/connect/DOIT_DJB/djb/home

Delhi Transco Limited; Website:

http://dtl.gov.in/d/AboutUs.aspx

DMRC, Delhi; Delhi Metro Rail Corporation; Website: http://www.delhimetrorail.com/

DOS, 2015; Website: http://dos.gov.in/dms.aspx

DST Road Map- Landslide; Landslide Risk Management in India; Department of Science \& Technology, Ministry of Science and Technology

DST-Seismology, 2015; Department of Science \& Technology, Ministry of Science and Technology

Website:http://dst.gov.in/scientific-programme/serseismicity.htm

DTC, 2015; Delhi Transport Corporation; Website: http://www.delhi.gov.in/wps/wcm/connect/DOIT_DTC/dtc/hom

Gautam P. K., 2013; Role of the Indian Military in Disasters; Institute for Defence Studies and Analysis, July 5, 2013; Website:

http://www.idsa.in/idsacomments/RoleoftheIndianMilitaryinDis asters_pkgautam_050713.html

Guzman, 2003; Towards Total Disaster Risk Management Approach, International Training Program on Total Disaster Risk Management, June 2003, Kobe, Japan; Asian Disaster Reduction Centre

Hec-RAS; US Army Corp's, Hydrologic Engineering Center, River Analysis System;

Website: http://www.hec.usace.army.mil/software/hec-ras/

Indian STI Policy, 2013; Indian Science, Technology and Innovation Policy

JICA, Japan International Cooperation Agency; Water Resources and Disaster Management; Website: http://www.jica.go.jp/english/our_work/thematic_issues/water/o verview.html

Kashif N. Q. and Abdul H. A., 2013; A Survey on Intelligent Transportation Systems; Middle-East Journal of Scientific Research 15 (5): 629-642, 2013;

MCD, Delhi; Municipal Corporation of Delhi; Website: http://www.mcdonline.gov.in/ 
MCIT-CERT-In, 2015; Indian Computer Emergency Response Team; Department of Information and Information Technology, Ministry of Communications \& Information Technology

Website: http://www.cert-in.org.in/

MEFCC-HSMD, 2015;

Website: http://envfor.nic.in/division/introduction-12

MHA-IDRN; ICT for Disaster Risk Reduction, The Indian Experience

MHA-NDMI; National Disaster Management, Ministry of Home Affairs ,Website: http://www.ndmindia.nic.in/

MIKE 11; DHI;

Website: https://www.mikepoweredbydhi.com/products/mike-11

MOES, Cyclone Prediction; Ministry of Earth Sciences; Website: https://www.moes.gov.in/programmes/cyclone-prediction

MOES-EHA, 2015; Earthquake Hazard Assessment, Ministry of Earth Sciences

Website: http://moes.gov.in/programmes/earthquake-hazardassessment

MOES-EWSTSS, 2015; Early warning system for tsunami and storm surges, Ministry of Earth Sciences

Website: http://moes.gov.in/programmes/early-warning-systemtsunami-and-storm-surges

MOES-IMD, 2015; India Meteorological Department, Ministry of Earth Sciences

Website:

http://www.imd.gov.in/services/others/hydrometeorology-

flood.htm

MOES-INCOIS, 2015; Indian National Centre for Ocean Information Services, Ministry of Earth Sciences

Website: http://www.incois.gov.in/portal/index.jsp

MOWRRDGR, 2015; Ministry of Water Resources, River Development \& Ganga Rejuvenation

Website: http://wrmin.nic.in/forms/list.aspx?lid=239

NACO, 2015; National Aids Control Organization; Department of Health \& Family Welfare, Website: http://www.naco.gov.in/NACO/About_NACO/Vision_and_Value $\mathrm{s} /$

National Cyber Security Policy, 2013; Deity, Ministry of Communication and Information Technology

National Oil Spill Disaster Contingency Plan (05-August 2013); Ministry of Defence, Website: http://www.mod.nic.in/forms/list.aspx?Id=51\&lid=2101

Nature Geoscience 3, 157 - 163 (2010); Tropical cyclones and climate change

Neuvel, J. and S. Zlatanova, 2006, The void between risk prevention and crisis response, In: Fendel \& Rumor (Eds); Proceedings of UDMS'06 Aalborg, Denmark May 15-17, 2006, TU Delft, 2006, pp. 6.1-6.14

New Delhi Municipal Council; Website: https://www.ndmc.gov.in/AboutNdmc/NAboutus.aspx
NOAA Center for Tusnami Research; National Oceanic and Atmospheric Administration

Website: http://nctr.pmel.noaa.gov/

Noran, O., 2014; Collaborative Disaster Management; An Interdisciplinary Approach. Computers in Industry, 65(6), 10321040

Patwardhan A., Ajit M., 2007; Disaster Prevention, Preparedness and Management and Linkages with Climate Change Adaptation, September 2007; Technology Information, Forecasting and Assessment Council, New Delhi

Planning Commission, Approach to the 12th Plan; Managing the Environment and Ecology

Planning Commission, 2011; Working Group Report on Flood Mgmt. \& Region Specific Issues for XII Plan

Public Works Department, Delhi; Website: https://www.pwddelhi.com/

Revenue Department, Delhi; Website: http://www.delhi.gov.in/wps/wcm/connect/DoIT_Revenue/reve nue/home/

TransCAD; Transport Application Software Website: www.calipercom/tcovu.htm

UNSIDR, 2009; Hydro climatic disasters in water resources management: training manual, The United Nations Office for Disaster Risk Reduction

Urban Development Department, Delhi; Website: http://delhi.gov.in/wps/wcm/connect/doit_udd/Urban+Develop ment/Home

Working Group on Disaster Management, 2006; REPORT OF THE WORKING GROUP ON DISASTER MANAGEMENT FOR THE ELEVENTH FIVE YEAR PLAN (2007-2012), The Planning Commission, Dec. 2006

Zlatanova, S., P. van Oosterom and E. Verbree, 2006, Geoinformation supports management of urban disasters, In: Open House International, Vol. 31, No.1, March 2006, pp. 62-79 